prepared; the study of emulsion paints comprising homo- and co-polymer systems has indicated a correlation between water-resistance, hardness and flexibility of latex films, and polymer composition; and the investigation of polyethers from polyols and propylene oxide has assisted the rapid growth of the polyurethane foam industry. Both the coal chemicals fellowship and the petroleum fellowship

\title{
LABOUR TURNOVER
}

$\mathrm{L}$ ABOUR turnover has been a subject of inquiry and discussion since interest was first focused on the problem during the First World War. It is commonly regarded as a source of serious economic waste. The level of turnover in a firm is often regarded as an index of morale among the employees.

Research workers have attempted to analyse the causes of labour turnover by relating it to different groups of factors. The most important of the external factors are the level of employment and the availability of alternative work. The internal factors are the composition of the labour force itself, that is to say, whether men or women are employed, whether they are skilled or unskilled; the length of time workerg have been employed, their age and the location of their homes. Wage rates, hours and conditions of work and the personal relationships existing within a firm may also have important effects on labour turnover.

The findings of research do not appear to have helped mansgements very much in their efforts to reduce labour turnover. The British Institute of Management survey of 1949 and 1950, covering approximately two hundred companies, showed annual labour turnover rates varying from 13 per cent to 59 per cent for men and from 24 per cent to 75 per cent for women per annum. These are industry rates. Individual companies fluctuated below and above this range. Labour turnover was calculated on the basis of :

Number of leavers in period under review Average number of persons employed during same period

Commonly agreed facts about labour turnover are that in any given period it is heavier among shortservice employees than among those of longer service and that much of it does not represent true mobility but, from the social point of view, useless changes from one job to another.

What has not been established is to what extent labour turnover matters to the individual company and to society and the extent to which labour turnover can be measured in financial terms or whether its effects are largely intangible and in any event non-financial.

Excessive labour turnover is assumed to cause waste and inefficiency. Few studies have attempted to find out what exactly is the extent of this waste. One of the drawbacks is the difficulty of measurement. The effects of labour turnover are widespread and varied and attempts to assess them in financial terms can easily become either over-simplified or over-imaginative and remote from verifiable facts.

An appraisal of the importance of labour turnover to industry cannot be complete unless there is some estimate of its financial effects. Certain effects as, cover a wide field and, under the power rectifier fellowship, laboratory development of the first new power rectifier was completed and the growth of highly perfect single crystals of silicon and germanium has been studied. New organosilicon compounds, monomers and polymers have been prepared under the silicones fellowship, including some hybrid organotin organosiloxane compounds. for example, the impact on the morale of the working group of a continually changing labour force, cannot be assessed in financial terms. The more tangible costs are also important.

What has been noeded is a series of published case-studies of the experience and of the financial cost of labour in individual concerns. The British Institute of Management has now published a series of sixteen such studies*. The studies have been of the cost of labour turnover among direct production workers. No studies have been undertaken among clerical or selling staff.

The data provided by these case-studies and by supplementary information obtained from a large number of firms show that :

(1) In five out of sixteen studies, labour turnover was adding $10 \mathrm{~s}$. or more per week to the wage cost of each individual employed.

(2) The main factors which appear to affect labour turnover cost are the impact of learners on production, the extent to which saleable production is lost through labour turnover and the methods used to make up production losses.

(3) The amount spent on training, induction and interviewing is a matter of company policy and will naturally affect the level of its labour turnover cost. Money spent in this way, however, has a constructive result and is not waste, as is the cost arising from other categories.

(4) Labour turnover has certain long-term effects which are not measurable in financial terms. Most important of these are the effect of high labour turnover on the morale of the work force, the wear and tear on supervisory staff and the loss of customer's' goodwill by failure to fulfil orders and to meet delivery dates. To combat these effects by reducing labour turnover, it seems worth spending money on training, induction and interviewing.

(5) Labour turnover appears to be most costly in those firms where there is a high proportion of semiskilled jobs peculiar to the company itself. This is because the training period is often long and it is rare to find new employees with experience of similar work. The recognized skilled occupations and the relatively unskilled ones, for example, labouring and cleaning, do not involve companies in high training costs.

(6) The results of the inquiry as a whole suggest that keeping labour turnover low may be a relatively expensive business, almost as expensive as allowing it to increase with consequent increased production costs and sales losses. The decision about how much to spend on redueing labour turnover must be based not only on the figures of tangible waste but also on management's estimate of the seriousness of the non-financial aspects.

T. H. HAWKINS

" "Cost of Labour Turnover", 17s. $6 d$. 